



\section{(Criteria voor) brand- en rookdetectiesystemen in technische ruimten van veestallen in de intensieve veehouderij}

Een inventariserende studie

M.H. Bokma-Bakker, H.H. Ellen en Y.S.M. Goselink

Dit onderzoek is uitgevoerd door Wageningen Livestock Research, in opdracht van en gefinancierd door het Ministerie van Landbouw, Natuur en Voedselkwaliteit, in het kader van het Beleidsondersteunend onderzoek thema 'Systeeminnovatie Veehouderij' (BO-43-013.01)

Wageningen Livestock Research

Wageningen, februari 2020

Rapport 1229 
Bokma-Bakker, M.H., H.H. Ellen en Y.S.M. Goselink, 2020. (Criteria voor) brand- en rookdetectiesystemen in technische ruimten van veestallen in de intensieve veehouderij. Een inventariserende studie. Wageningen Livestock Research, Rapport 1229.

Samenvatting NL Op verzoek van het ministerie van LNV is een inventariserend onderzoek uitgevoerd naar brand- en rookdetectiesystemen die geschikt zijn voor gebruik in technische ruimten van veehouderijen, en naar de criteria waaraan dergelijke systemen zouden moeten voldoen.

Summary UK At the request of the Ministry of LNV, an inventory study was carried out regarding fire and smoke detection systems that are suitable for use in technical areas of livestock farms, and regarding the criteria that such systems should meet.

Dit rapport is gratis te downloaden op https://doi.org/10.18174/514402 of op www.wur.nl/livestock-research (onder Wageningen Livestock Research publicaties).

(C) 2020 Wageningen Livestock Research

Postbus 338, 6700 AH Wageningen, T 03174839 53, E info.livestockresearch@wur.nl, www.wur.nl/livestock-research. Wageningen Livestock Research is onderdeel van Wageningen University \& Research.

Wageningen Livestock Research aanvaardt geen aansprakelijkheid voor eventuele schade voortvloeiend uit het gebruik van de resultaten van dit onderzoek of de toepassing van de adviezen.

Alle rechten voorbehouden. Niets uit deze uitgave mag worden vermenigvuldigd en/of openbaar gemaakt worden door middel van druk, fotokopie, microfilm of op welke wijze dan ook zonder voorafgaande toestemming van de uitgever of auteur.

Wageningen Livestock Research is NEN-EN-ISO 9001:2015 gecertificeerd.

Op al onze onderzoeksopdrachten zijn de Algemene Voorwaarden van de Animal Sciences Group van toepassing. Deze zijn gedeponeerd bij de Arrondissementsrechtbank Zwolle.

Wageningen Livestock Research Rapport 1229 


\section{Inhoud}

$\begin{array}{ll}\text { Voorwoord } & 5\end{array}$

$\begin{array}{lll}1 & \text { Aanleiding en kennisvragen } & 7\end{array}$

$\begin{array}{llr}2 & \text { Aanpak } & 8\end{array}$

$3 \quad$ Technische 'ruimten' in de intensieve veehouderij 9

$\begin{array}{lll}3.1 & \text { Technische ruimten op pluimveebedrijven } & 10\end{array}$

3.1.1 Leghennenbedrijven 10

3.1.2 Vleeskuikenbedrijven 10

3.2 Technische ruimten op varkensbedrijven 11

3.3 Technische ruimten op vleeskalverbedrijven 11

$4 \quad$ Brandfasen en criterium 'snelle' detectie $\quad 13$

$\begin{array}{lrr}5 & \text { Criteria } & 15\end{array}$

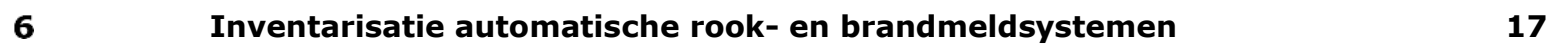

$7 \quad$ Toetsing categorieën detectie-systemen aan de ontwikkelde criteria $\quad 21$

$8 \quad$ Kosten van potentieel toepasbare systemen in de sectoren 23

$\begin{array}{llr}9 & \text { Conclusies en discussie } & 24\end{array}$

$\begin{array}{ll}\text { Literatuur } & 26\end{array}$ 


\section{Voorwoord}

Deze inventariserende studie naar brand- en rookdetectiesystemen voor technische ruimten van veestallen is uitgevoerd op verzoek van het ministerie van LNV. Bij de totstandkoming ervan hebben diverse personen een waardevolle bijdrage geleverd. In het bijzonder willen wij de volgende personen bedanken voor hun constructieve medewerking:

- de vertegenwoordigers vanuit systeemexperts, bouwadviesbureaus, verzekeraars en gebruikers, die hebben deelgenomen aan de gezamenlijke discussiebijeenkomst en/of bilateraal informatie met ons hebben gedeeld;

- de leden van de werkgroep Actieplan Brandveilige Veestallen 2018-2022, voor hun constructieve reacties op (tussentijdse) resultaten en rapportage.

Namens het onderzoeksteam,

Martien Bokma-Bakker (projectleider) 


\section{$1 \quad$ Aanleiding en kennisvragen}

Mede naar aanleiding van een Kamervraag (Motie lid Geurts d.d. 24-1-2019) heeft het ministerie van LNV aan Wageningen Livestock Research gevraagd om twee kennisvragen in relatie met stalbranden te beantwoorden:

- Een inventariserend onderzoek naar brand- en rookdetectiesystemen die geschikt zijn voor gebruik in technische ruimten van veehouderijen [daarbij ook aandacht voor verenigbaarheid van detectiesystemen met bestaande systemen zoals die voor klimaat].

- Als aanvulling op de voorgaande kennisvraag: aan welke criteria moeten detectiesystemen bij gebruik in technische ruimten van veehouderijen voldoen.

Gegeven achtergrond voor de kennisvragen: 'Het gebruik van de juiste detectiesystemen in technische ruimten van veehouderijen draagt bij aan het beperken van het aantal dierlijke slachtoffers bij stalbranden. Het is van belang om vast te stellen aan welke criteria dergelijke systemen moeten voldoen voor gebruik in veehouderijen.'

Beide kennisvragen zijn in dit document geïntegreerd beantwoord. 


\section{Aanpak}

De kennisvragen zijn beantwoord voor de intensieve veehouderijsectoren (varkens, pluimvee en vleeskalveren) en gericht op de technische ruimten van veehouderijen. Daarbij zijn de volgende subvragen beantwoord:

- Wat verstaan we in dit project onder 'technische ruimten'? Hoe zien 'technische ruimten' er bij de betreffende diersectoren uit? [in afstemming met werkgroep Actieplan Stalbranden]

- Welke categorieën van rook- en branddetectiesystemen zijn er beschikbaar voor technische ruimten in veestallen? Wat is een indicatie van bijbehorende kosten? [via oriënterende internetsurvey en bilaterale gesprekken/brainstormbijeenkomst met systeemexperts, bouwadviesbureaus]

- Aan welke criteria dienen detectiesystemen in technische ruimten van veestallen te voldoen? Met als belangrijk aandachtspunt een criterium voor 'snelle' detectie van brand in technische ruimten in relatie met handelingsperspectief voor het voorkómen van dierlijke slachtoffers [via inventarisatie van bestaande NEN-normen, bilaterale gesprekken en brainstormbijeenkomst met brandexperts, systeemexperts, adviesbureaus en gebruikers]

- Toetsing van de geïnventariseerde typen systemen aan de opgestelde criteria [WLR]

In de volgende paragraaf gaan we in op de definitie en kenmerken van 'technische ruimten' binnen de betrokken sectoren. 


\section{Technische 'ruimten' in de intensieve veehouderij}

Veestallen moesten tot april 2014 voldoen aan de algemene eisen die het Bouwbesluit stelt aan gebouwen met een lichte industriële functie. Om specifieke eisen aan de bescherming van dieren in stallen te kunnen stellen, zijn veestallen sinds 2014 als aparte subfunctie in het Bouwbesluit opgenomen. Daarbij zijn o.a. de eisen aan technische ruimten bij nieuwbouw aangescherpt. Het Bouwbesluit 2012, inclusief de wijzigingen daarop per 1-4-2014, geeft de volgende definities van technische ruimten in gebouwen, waaronder veestallen, en van brandcompartimenten.

Technische ruimte: Ruimte voor het plaatsen van de apparatuur, noodzakelijk voor het functioneren van het bouwwerk, waaronder in ieder geval begrepen een meterruimte, een liftmachineruimte en een stookruimte

Brandcompartiment: Gedeelte van een of meer bouwwerken bestemd als maximaal uitbreidingsgebied van brand

Algemeen: Daarnaast zijn er enkele aspecten waarmee bij de indeling van ruimtes en plaatsing van installaties rekening moet worden gehouden. Dit zijn o.a.:

- opstellingsruimte/stookruimte (CV-ketels) volgens NPR3378; Hfst 22 (NPR=Nationale Praktijk Richtlijn);

- verdeelinrichting ('stoppenkast') in apart brandcompartiment volgens bouwbesluit wijziging 1 april 2014

Bij stallen die vóór 1-4-2014 zijn vergund, geldt dat technische ruimten die groter zijn dan $50 \mathrm{~m}^{2}$ en/of een CV-ketel bevatten van $>130 \mathrm{~kW}$ in een apart brandcompartiment geplaatst dienen te zijn (30 minuten bestand tegen branddoorslag en brandoverslag). Dit betekent dat er ook stallen van vóór 2014 zijn met technische ruimten die niet in een apart brandcompartiment zijn geplaatst.

Bij stallen die ná 1-4-2014 zijn vergund, geldt dat alle technische ruimten aparte brandcompartimenten moeten zijn, en 60 minuten bestand tegen branddoorslag en brandoverslag.

$\mathrm{Er}$ is in het Bouwbesluit o.a. voor veestallen niet nader gedefinieerd welke apparatuur wordt verondersteld noodzakelijk te zijn voor het functioneren van het bouwwerk. Zo is het bijvoorbeeld de vraag of voerinstallaties, eierinpakmachines e.d. hier ook onder vallen: deze zijn in strikte zin niet noodzakelijk voor het functioneren van het bouwwerk. In afstemming met de opdrachtgever is besloten om voor beantwoording van de kennisvragen over detectiesystemen de volgende definitie van technische ruimte te hanteren:

Een technische ruimte is een van de dierverblijven afgescheiden ruimte door middel van een dichte wand, zodat er een mogelijkheid is om een vorm van branddetectie in deze specifieke ruimte toe te passen. In deze ruimte kunnen verschillende installaties aanwezig zijn. Ook kan de ruimte voor andere werkzaamheden worden benut, zoals bijvoorbeeld de centrale gang op een varkensbedrijf of de ruimte met de eierinpakker op een leghennenbedrijf [deze situatie komt in veel bestaande stallen voor in diverse combinaties].

Hierna is voor de pluimvee-, varkens- en vleeskalversector aangegeven welke technische apparatuur op de bedrijven in de betreffende sector voorkomt, welke apparatuur daarvan doorgaans in een eigen, afzonderlijke technische ruimte is geplaatst (al dan niet zijnde een apart brandcompartiment), en welke apparatuur in een gezamenlijke technische ruimte en/of multifunctionele ruimte (met uitzondering van functie dierverblijf) voorkomt. We gaan er vanuit dat in bestaande situaties deze laatste ruimte doorgaans geen apart brandcompartiment is. Bij iedere tabel wordt een korte toelichting gegeven over het gebruik en plaatsing van enkele installaties. 
NB: De installaties staan in willekeurige volgorde en we pretenderen niet volledig te zijn. In de praktijk komen er veel verschillende situaties voor, ieder bedrijf kent zijn eigen indeling.

\subsection{Technische ruimten op pluimveebedrijven}

\subsubsection{Leghennenbedrijven}

Op een leghennenbedrijf is een ruimte aanwezig waarin de eierinpakker staat. Deze ruimte is, ook in bestaande stallen, afgescheiden van de dierruimte met een wand, en staat soms in een apart gebouw. In bestaande situaties werden hier veel installaties geplaatst die nodig zijn voor aansturing van klimaat e.d. Ook de groepenkast voor de elektra (de verdeelinrichting) is vaak in deze ruimte geplaatst. De regelkast voor de aansturing van de mestbanden (en eventueel droogtunnel) is vaak in de directe omgeving van de dwarsafvoerband, in de dierruimte, geplaatst. Apparatuur die (veel) geluid veroorzaakt (zoals voerweger, compressor, bronpomp, noodstroomaggregaat) zit overwegend al in een eigen aparte ruimte. Op leghennenbedrijven is er geen warmtevraag, behalve voor warmwater (handen wassen, douche). Het vermogen van een eventuele CV-ketel is daardoor beperkt en hoeft daardoor conform het Bouwbesluit niet in een apart brandcompartiment te zijn geplaatst.

Tabel 1 Plaatsing installaties in ruimten op een leghennenbedrijf [ab $=$ alleen bij stallen van ná 2014 verplichte plaatsing in apart brandcompartiment).

\begin{tabular}{|c|c|c|}
\hline $\begin{array}{l}\text { Eigen technische ruimte } \\
\text { Eigen detectie }\end{array}$ & $\begin{array}{l}\text { Gezamenlijke technische ruimte en/of } \\
\text { multifunctionele ruimte } \\
\text { Gezamenlijke detectie }\end{array}$ & $\begin{array}{l}\text { Eigen ruimte, } \\
\text { geen technische ruimte }\end{array}$ \\
\hline Groepenkast elektra (verdeelinrichting) ab & Eierinpakker (met eventueel stapelrobot) & Kantoorruimte met pc \\
\hline Voermenger/-weger & Koeling voor eieropslag & Opslag reserveonderdelen \\
\hline $\begin{array}{l}\text { Bronpomp eigen watervoorziening }+ \\
\text { behandelingsinstallatie }\end{array}$ & Regel-/schakelkasten ${ }^{1}$ & Koelkast (met medicijnen) \\
\hline
\end{tabular}

${ }^{1}$ klimaat/voer/mestbanden (en droogtunnel)/legnest/strooiselschuif/luchtwasser (vaak in ruimte bij wasser)

\subsubsection{Vleeskuikenbedrijven}

Bij vleeskuikenstallen zijn de technische installaties in bestaande stallen veelal aanwezig in een zogenaamde 'voorruimte'. Vanuit deze voorruimte is er toegang tot de dierverblijven, waarbij soms meerdere dierverblijven bereikbaar zijn vanuit de voorruimte. Ook hier geldt dat installaties die (veel) geluid produceren doorgaans in een aparte ruimte zijn geplaatst.

Vleeskuikenstallen hebben een hoge warmtebehoefte. Voorheen werden voornamelijk heaters met een open verbranding toegepast (zgn. heteluchtkanonnen). Zowel vanwege een bijdrage aan de reductie van ammoniak als vanuit brandveiligheid worden meer verwarmingsinstallaties toegepast die worden gevoed met warmwater. Ook komt vaker vloerverwarming voor als verwarmingssysteem. Bij deze vormen van verwarming zijn of CV-ketels aanwezig (>130 kW), die conform het Bouwbesluit in een apart brandcompartiment moeten zijn geplaatst, maar ook vaak een houtgestookte ketel. Deze laatste bevindt zich meestal in een aparte loods, samen met de opslag van hout.

Tabel 2 Plaatsing installaties in ruimten op een vleeskuikenbedrijf $[\boldsymbol{A B}=$ ook bij stallen van vóór 2014 verplichte plaatsing in apart brandcompartiment; $\boldsymbol{a} \boldsymbol{b}=$ alleen bij stallen van ná 2014 verplichte plaatsing in apart brandcompartiment).

\begin{tabular}{|c|c|c|}
\hline Eigen technische ruimte & $\begin{array}{l}\text { Gezamenlijke technische ruimte en/of } \\
\text { multifunctionele ruimte }\end{array}$ & Eigen ruimte, \\
\hline Groepenkast elektra (verdeelinrichting) ab & Regel-/schakelkasten ${ }^{1}$ & Kantoorruimte met pc \\
\hline Voermenger/-weger & Hogedrukreiniger & Opslag reserveonderdelen \\
\hline $\begin{array}{l}\text { Bronpomp eigen watervoorziening }+ \\
\text { behandelingsinstallatie }\end{array}$ & & Koelkast (met medicijnen) \\
\hline \multicolumn{3}{|l|}{$\begin{array}{l}\text { CV-ketel / Houtkachel (>130kW) } \\
\text { /warmtepomp AB }\end{array}$} \\
\hline Compressor & & \\
\hline
\end{tabular}

${ }^{1}$ klimaat/voer/luchtwasser (vaak in ruimte bij wasser) 


\subsection{Technische ruimten op varkensbedrijven}

Vooral op varkensbedrijven met een brijvoerinstallatie zijn veel installaties aanwezig. Deze zijn ook in bestaande situaties al ondergebracht in een aparte ruimte. Verder is op veel bedrijven een centrale gang aanwezig, langs de zijkant van de stal of centraal in het midden. De afdelingen sluiten aan op deze gang. In bestaande stallen wordt deze gang ook vaak gebruikt voor het plaatsen van de verdeelinrichting en centrale regel- en schakelkasten. Voor de klimaatbeheersing is bij iedere afdelingsdeur een extra unit geplaatst voor een snelle bediening.

Tabel 3 Plaatsing installaties in ruimten op een varkens [ $\boldsymbol{A B}=$ ook bij stallen van vóór 2014 verplichte plaatsing in apart brandcompartiment; $\boldsymbol{a} \boldsymbol{b}=$ alleen bij stallen van ná 2014 verplichte plaatsing in apart brandcompartiment).

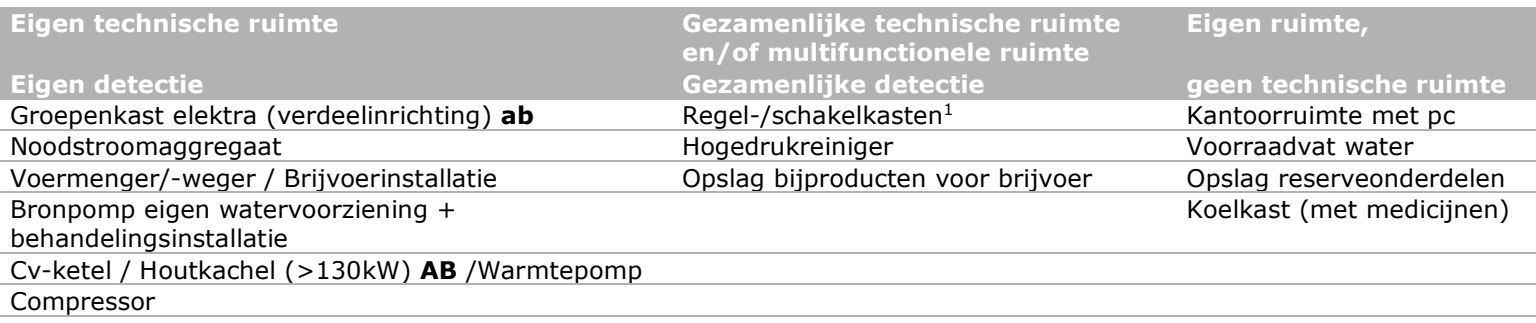

${ }^{1}$ klimaat/voer/luchtwasser (vaak in ruimte bij wasser)

\subsection{Technische ruimten op vleeskalverbedrijven}

Op een kalverbedrijf voor de productie van rosévlees zijn twee productiestadia te onderscheiden: de opfok tot ca. 12 weken en de afmest. Er zijn bedrijven die zich hebben gespecialiseerd in één van beide stadia, maar ook bedrijven waar beide voorkomen. De opfok tot 12 weken leeftijd is wat betreft voorzieningen en installaties vergelijkbaar met die van de blankvleesproductie. Voor de afmestperiode zijn geen specifieke installaties op het bedrijf aanwezig. Deze dieren vragen geen geklimatiseerde ruimte en krijgen overwegend ruwvoer.

Bij de productie van witvlees is de bereiding van melk een belangrijk element in de bedrijfsvoering. De apparatuur hiervoor is overwegend in een aparte ruimte geïnstalleerd. Bij de bereiding is warmwater nodig waarvoor of CV-ketels of elektrische boilers aanwezig zijn of een houtkachel. Soms ook gecombineerd met opwarming op het dak d.m.v. zonnewarmte. CV-ketels en elektrische boilers zullen in bestaande situaties veelal in dezelfde ruimte geplaatst zijn als de melkbereidingsinstallatie. Gezien de capaciteit van de CV-ketel ( $>130 \mathrm{~kW}$ ) dient dat dan wel een apart brandcompartiment te zijn. Naast een verwarmingsunit voor warmwater is er ook warmtevraag voor de verwarming van de dierruimte. Deze tweede installatie (CV-ketel of houtkachel) is veelal in een aparte ruimte geplaatst.

Tabel 4 Plaatsing installaties in ruimten op een vleeskalverbedrijf [AB = ook bij stallen van vóór 2014 verplichte plaatsing in apart brandcompartiment; $\boldsymbol{a} \boldsymbol{b}=$ alleen bij stallen van ná 2014 verplichte plaatsing in apart brandcompartiment).

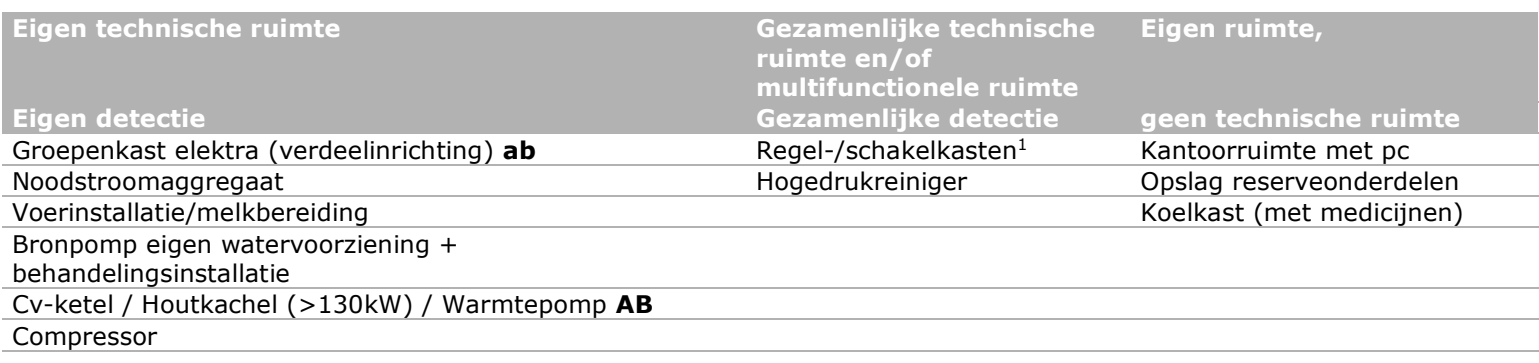

${ }^{1}$ klimaat/voer/luchtwasser (vaak in ruimte bij wasser) 


\section{Samengevat}

Volgens de definitie die we in dit beknopte onderzoek hanteren komen er vele varianten van technische ruimten voor op de intensieve veehouderijbedrijven:

- Alleen stallen vergund ná 1-4-2014: alle technische ruimten met installaties noodzakelijk voor het functioneren van het bouwwerk zijn tevens apart brandcompartiment (60 minuten brandwerend);

- Stallen vergund vóór 1-4-2014: alle technische ruimten met installaties noodzakelijk voor het functioneren van het bouwwerk die groter zijn dan $50 \mathrm{~m}^{2}$ en/of een CV-ketel bevatten van $>130 \mathrm{~kW}$ zijn tevens apart brandcompartiment (30 minuten brandwerend);

- Daarnaast alle stallen: diverse andere typen technische ruimten (van de dierruimtes afgescheiden ruimten met één of meer installaties) komen voor, en dat kunnen ook ruimten zijn waar andere bedrijfsgerelateerde werkzaamheden plaatsvinden (multifunctionele ruimten). Doorgaans zijn deze 'technische ruimten' geen aparte brandcompartimenten. 


\section{$4 \quad$ Brandfasen en criterium 'snelle' detectie}

Bij ontwikkelen van criteria voor rook- en branddetectiesystemen is het allereerst belangrijk om vast te stellen wat 'tijdige' of 'snelle' detectie inhoudt in relatie met beperken van dierlijke slachtoffers bij branden die ontstaan in technische ruimten van veestallen. Hierbij is de relatie met de fasen van brandontwikkeling relevant.

\section{Brandfasen}

Indien er voldoende zuurstof aanwezig is, dan doorloopt het proces van brandontwikkeling drie stadia, namelijk de ontwikkelingsperiode, de volledig ontwikkelde periode en de doofperiode (IFV, 2017).

[Een andere vaak gebruikte beschrijving is: smeulfase (stadium voor vlammen), ontwikkelfase (lokale brand pre-flash-over), volledig ontwikkelde fase (post flash-over), en dooffase]

De ontwikkelingsperiode en de volledig ontwikkelde periode worden gescheiden door een overgang: de flash-over. Tijdens deze overgang is er een plotselinge stijging van de temperatuur. Bij elke periode hoort een bepaald temperatuurbereik. De brandkromme is een schematische weergave van het verband tussen de temperatuur en de tijd bij een brand in een afgesloten ruimte. Het is een model en dus een vereenvoudiging van de werkelijkheid (Figuur 1).

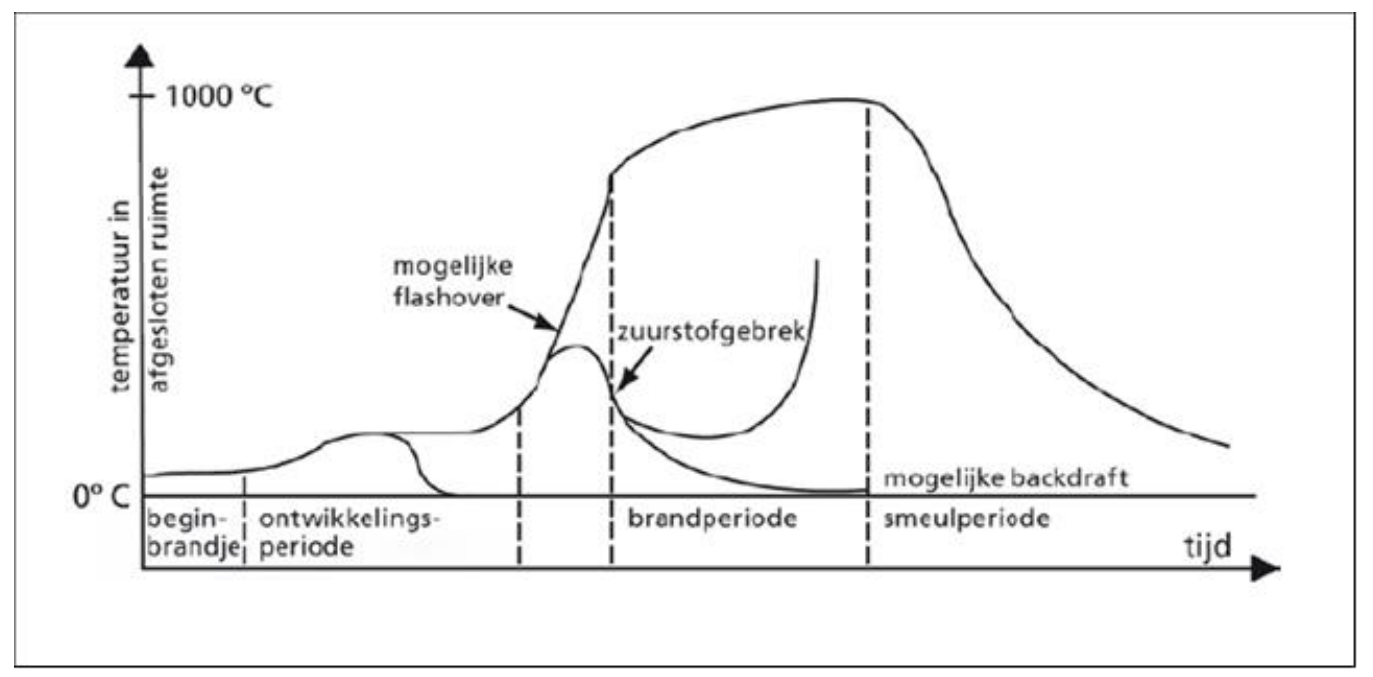

Figuur 1 Brandkromme (bron: IFV, 2017 https://www.ifv.nl/kennisplein/Documents/201712IFV-Basis-voor-brandveiligheid.pdf).

De ontwikkelingsperiode start met een beginnende brand, waarna de brand langzaam tot ontwikkeling komt. Uiteindelijk kan er een laag hete rookgassen bij het plafond ontstaan, die warmte uitstraalt naar andere voorwerpen in de ruimte, waardoor er nog meer rookgassen ontstaan en opstijgen. Bij een temperatuur tussen 200 en $300{ }^{\circ} \mathrm{C}$ kan er een brandbaar gas-luchtmengsel ontstaan en een flash-over (vlamoverslag) optreden. De vuurbal die ontstaat heeft zeer hoge temperaturen. Na de flash-over komt de brand in de volledig ontwikkelde periode: de temperatuur neemt toe tot 600 á $1000{ }^{\circ} \mathrm{C}$, mede afhankelijk van de aanwezige hoeveelheid brandbaar materiaal en de aanwezigheid van zuurstof, en al het brandbare materiaal zal opbranden zolang er voldoende zuurstof aanwezig is. In de smeulperiode (of de 'dooffase') kan het resterende brandbare materiaal roodgloeiend zijn, terwijl de vlammen zijn gedoofd.

De normtijd voor flash-over is 15 minuten (IFV, 2017). In het beginstadium van de brand is brandbestrijding mogelijk, op voorwaarde van een snelle opvolging op een tijdige detectie. Na de 
flash-over is het betreffende brandcompartiment 'niet meer te redden', en zal bij de bestrijding worden ingezet op het voorkomen van overslag naar andere compartimenten.

\section{'Snelle' detectie in relatie met typen technische ruimten}

NEN 2535:2017 formuleert als doel voor brandmeldinstallaties (branddetectiesystemen) het volgende: 'Een brandmeldinstallatie in een gebouw heeft tot doel een begin van brand in een dusdanig stadium te ontdekken, lokaliseren en signaleren, dat het bestrijden ervan tijdig kan plaatsvinden en maatregelen kunnen worden getroffen om mens, dier en inventaris, gebouw en milieu veilig te stellen, waardoor ongevallen en/of schade worden beperkt respectievelijk voorkomen. De brandmeldinstallatie heeft daarnaast tot doel om intern een speciale groep personen zoals de bedrijfshulpverlening en/of de brandbestrijdingsorganisatie te alarmeren. De intern gealarmeerde personen kunnen in afwachting van de brandweer reeds met de redding en blussing een aanvang nemen.' [einde citaat, NEN 2535, pag. 5]

Dit doel geldt onverminderd voor rook- en branddetectiesystemen in technische ruimten van veestallen, met dien verstande dat in de opdracht een belangrijke focus ligt bij het voorkómen van dierlijke slachtoffers, en dat onder 'bedrijfshulpverlening' in dit geval de veehouder, medewerkers en/of andere personen die het brandalarm krijgen wordt verstaan.

'Snelle' detectie betekent in dit onderzoek dat de brand in een dusdanig stadium wordt ontdekt, dat bestrijden ervan tijdig kan plaatsvinden zodat overslag naar dierverblijven en/of dierlijke slachtoffers (o.a. door rook) worden voorkomen. In combinatie met de beschrijving van het verloop van een brand kan een criterium van 'snelle detectie voor de verschillende typen technische ruimten in veestallen worden afgeleid.

Technische ruimten die geen apart brandcompartiment zijn

Detectie van brand in technische ruimten van stallen die geen apart brandcompartiment zijn, dient ruim vóór de flash-over, in de beginfase of in het begin van de ontwikkelfase van de brand, plaats te vinden. Dat wil zeggen: na één tot enkele minuten. De effecten van temperatuursverhoging zijn in het beginstadium (tenzij er sprake is van een explosie) nog slechts lokaal merkbaar. In dat geval kan de brand nog lokaal worden bestreden en geblust. Er kan overigens al wel gevaar zijn voor in de ruimte aanwezige of met de ruimte verbonden mensen en dieren vanwege de rookontwikkeling.

NB. Snelle detectie heeft in technische ruimten die geen apart brandcompartiment zijn vooral zin als een snelle opvolging mogelijk is, namelijk het bestrijden van de brand via effectieve automatische blussystemen of door personen die in de buurt aanwezig zijn (personeel/buren), aangezien de aanrijtijd van de brandweer al minimaal 10 minuten is. Na de flash-over (na ca. 15 minuten) is het bestrijden van de brand in de brandende ruimte zelf niet meer mogelijk. Het blussen richt zich dan op het gecontroleerd laten uitbranden van het compartiment en het voorkomen van overslag naar aangrenzende of nabijgelegen compartimenten en/of opstallen. Daarvoor biedt een snelle detectie natuurlijk wel voordelen, maar het beperken van dierlijke slachtoffers in het brandende compartiment is dan niet meer aan de orde.

Technische ruimten die wel een apart brandcompartiment zijn Met een brandwerendheid van 30 tot 60 minuten voordat branddoorslag of -overslag naar naastgelegen compartimenten plaatsvindt, is er meer handelingstijd om overslag van brand in een technische ruimte naar dierverblijven te voorkomen. Met de kanttekening dat ook een brandwerendheid van 30 minuten gezien de tijd tot flash-over en de minimale aanrijtijd voor de brandweer feitelijk te kort is om overslag te voorkomen. Om de schade in de ruimte zelf zo beperkt mogelijk te houden, is het ook in technische ruimten die brandcompartiment zijn gewenst dat een brand zo snel mogelijk wordt gedetecteerd, d.w.z. in de beginfase of in het begin van de ontwikkelfase van een brand. 


\section{$5 \quad$ Criteria}

Op basis van o.a. NEN 2535:2017 en een discussiebijeenkomst met systeemexperts, bouwadviesbureaus voor veehouderijbedrijven, gebruikers (vertegenwoordigers van veehouders) en brandweer zijn de belangrijkste criteria afgeleid voor rook- en branddetectiesystemen in technische ruimten van veestallen.

\section{Functionele eisen (wat moet het detectiesysteem kunnen)}

Doel van het systeem: 'snelle' detectie

Prestatie-eis in technische ruimten die geen apart brandcompartiment zijn: brand detecteren in de beginfase of in het begin van de ontwikkelfase van een brand, dat wil zeggen maximaal één tot enkele minuten na het ontstaan van de brand. [NB uit oogpunt van beperken van dierlijke slachtoffers alleen zinvol als een onmiddellijke opvolging (bestrijding) mogelijk is]

Prestatie-eis in technische ruimten die wel een apart brandcompartiment zijn: bij 30 minuten brandwerendheid dient de brand vóór de flash-over te zijn gedetecteerd (d.w.z. in de eerste 15 minuten na ontstaan). Bij 60 minuten brandwerendheid is er meer speelruimte. Echter, om ook schade aan technische apparatuur zoveel mogelijk te beperken dienen detectiesystemen de brand in een beginstadium te ontdekken.

Prestatie-eis voor de brandgrootte per technische ruimte

Het gaat hier om de brandgrootte die het detectiesysteem moet kunnen detecteren. De keuze van de te detecteren brandgrootte is afhankelijk van het te verwachten brandverschijnsel, het brandrisico en andere factoren zoals het ventilatiedebiet en de gebruiksfunctie van de betreffende technische ruimte. Doorgaans moet detectiegevoeligheid behorend bij brandgrootte 1 (polyurethaan brandmatten) of brandgrootte 2 (beukenhouten blokjes) worden gekozen. Bij specifieke risico's in de technische ruimte of als het risico op ongewenste meldingen te groot wordt, mag volgens NEN 2535 een andere brandgrootte worden gekozen. Genoemd wordt brandgrootte 5 (pvc-draad) om in een vroeg stadium brand in ruimten met elektrische risico's te detecteren (bv. via aspiratierookmelders, zie verder). En brandgrootte 7 (brandspiritus) in ruimten waar risico is op open branden (melding via vlammelders, zie verder), of in ruimten waar men voor thermische detectie moet kiezen omdat er omstandigheden in de ruimte zijn die op smeulbrand lijken.

Prestatie-eis voor ongewenste meldingen en onechte meldingen Om effectief te kunnen zijn en blijven mag het detectiesysteem niet meer dan een beperkt aantal ongewenste of onechte brandmeldingen geven (dit is ook duidelijk een gebruikerswens). Ook in technische ruimten met stof, vocht of ammoniak.

Ongewenste meldingen zijn meldingen van situaties die sterk op brand lijken, maar het niet zijn (bv. roken, laswerkzaamheden). Onechte meldingen zijn meldingen die het gevolg zijn van niet op brand lijkende verschijnselen (bv. opwervelend stof, vervuiling/erosie van de melder). NEN 2535 geeft rekenregels voor een maximum aantal ongewenste en onechte meldingen per jaar, afhankelijk van de risicoklasse per gebruiksfuncties (voor veestallen: industriefunctie) en het type detectiesysteem dat is toegepast.

\section{Ruimte en keuze systeem}

De keuze van een automatisch branddetectiesysteem moet tevens zijn afgestemd op de hoogte van de ruimte waarin de melder wordt geplaatst. De hoogte van technische ruimten in veestallen bedraagt doorgaans niet meer dan 6 meter, maar kan ook doorlopen tot de nok ( 8 tot 15 meter). In ruimtes met een maximale hoogte van 6-7,5 meter zijn in principe alle categorieën branddetectiesystemen toepasbaar. Een zorgvuldige afweging van geschikt detectiesysteem is van belang: als het type melder niet past bij de hoogte van de ruimte, kan bv. rookdetectie pas vertraagd optreden. De NEN 2535 geeft tevens indicaties van maximaal te bewaken oppervlaktes per type melder in relatie met hoogte van de te bewaken ruimte en de de dakhelling, alsmede over o.a. de gewenste positionering van de brandmelders. 
Doormelding van brandalarm en/of storingssignaal

Branddetectiesystemen in technische ruimten van veestallen zijnde geen langdurig brandwerende brandcompartimenten hebben uit oogpunt van beperken van dierlijke slachtoffers alleen zin als een snelle doormelding van het rook- of brandsignaal is gegarandeerd. Hiertoe is directe doormelding naar de (telefoon van de) veehouder, aanwezig personeel en/of andere personen in de directe omgeving van de veehouderij (familieleden, buren) geïndiceerd. Directe doormelding naar brandweercentrales behoort voor veehouderijen niet tot de mogelijkheden.

Bij koppeling van een detectiesysteem met automatische blussystemen dient er altijd gelijktijdig een doormelding van het rook-/brandsignaal naar de intern aangewezen personen te zijn. Dit is bij bepaalde thermische melders met automatische bluspatronen (bv. plaatsbaar in schakelkasten) niet altijd het geval: dit is risicovol, omdat na eerste blussing de brand weer op kan laaien en het bluspatroon dan leeg is.

Het spreekt voor zich dat ook storingen in het detectiesysteem op een of andere wijze aan de relevante interne personen worden doorgemeld.

\section{Gebruikerseisen (welke wensen hebben gebruikers)}

Tijdens de bijeenkomst met experts en gebruikers zijn de volgende gebruikerseisen, te stellen aan detectiesystemen in technische ruimten, genoemd:

- Hoge betrouwbaarheid: weinig onechte en ongewenste meldingen;

- Gebruiksvriendelijk en weinig onderhoud;

- $\quad$ Lage kosten (investerings- en jaarlijkse kosten);

- Bij voorkeur koppeling aan al bestaand systeem in het bedrijf (bv. klimaatcomputer);

- In het ideale geval is branddetectie onderdeel van een integraal systeem: na branddetectie directe doormelding en automatisch sluiten van branddeuren, stopzetten van draaiende mesten eierbanden om verspreiding naar naastgelegen compartiment te voorkomen, eventueel aanwezige automatische blussystemen activeren et cetera. Daarbij is aangegeven dat automatische blussystemen wel voldoende wateropbrengst moeten hebben: in de praktijk blijkt dit nogal eens een probleem te vormen (persoonlijke mededeling verzekeraar).

\section{Randvoorwaarden}

Om te blijven functioneren dient er regelmatig onderhoud te worden gepleegd aan branddetectiesystemen, regelmatige tests op werkzaamheid te worden uitgevoerd en een logboek van testen te worden bijgehouden.

Bouwbesluit 2012 (art. 6.19 en bijlage 1) geeft aan voor welke gebruiksfuncties van bouwwerken het verplicht is om (bepaalde) brandbeveiligingsinstallatie c.q. rookmelders en geldige inspectiecertificaten, afgegeven op grond van het CCV-inspectieschema Brandmeldinstallaties, voorhanden te hebben. Voor die betreffende gebruiksfuncties dienen autonome brandmeldinstallaties, die niet vallen onder NEN 2535, beheerd, gecontroleerd en onderhouden te worden conform NENnorm 2654-1+C1:2018 (Beheer, controle en onderhoud van brandbeveiligingsinstallaties - Deel 1: Brandmeldinstallaties). Deze Bouwbesluitbepalingen met betrekking tot brand- en rookmeldapparatuur gelden voor de gebruiksfuncties waar bijvoorbeeld kantoren, ziekenhuizen en scholen onder vallen.

Veehouderijen vallen onder de categorie 'lichte industriefunctie' van het Bouwbesluit, en voor deze gebruiksfunctie gelden de hierboven genoemde bepalingen niet. Toepassing van NEN 2654-1 is derhalve niet verplicht voor veehouderijbedrijven. Niettemin geeft de NEN 2654-1 wel handvatten die ook kunnen worden benut ten behoeve van een adequaat beheer, controle en onderhoud van branddetectiesystemen die geplaatst zijn/worden op veehouderijbedrijven. 


\section{Inventarisatie automatische rook- en brandmeldsystemen}

Naar het werkingsprincipe kan een onderscheid in de volgende typen van automatische brandmelders worden gemaakt (NEN 2535):

a. rookmelders, onder te verdelen in optische en ionisatierookmelders;

b. thermische melders, onder te verdelen in de diverse temperatuurklassen;

c. vlammenmelders, onder te verdelen in infrarood- en ultravioletvlammenmelders;

d. combinaties van bovengenoemde melders;

e. lineaire optische rookmelders;

f. lineaire thermische melders;

g. aspiratierookmelders.

Daarnaast zijn er nog andere typen automatische brandmelders verkrijgbaar, doorgaans voor specifieke toepassingen. De keuze van de automatische brandmelder is afhankelijk van de in het PVE vastgelegde eisen. Daarnaast moet de toegepaste apparatuur bestand zijn tegen de geldende storings- en omgevingsinvloeden (bron: NEN 2535).

Hierna is het resultaat weergegeven van een oriënterende internetsurvey naar de beschikbare rooken branddetectiesystemen voor technische ruimten in veestallen, aangevuld met inzichten van de experts tijdens de brainstormbijeenkomst.

a. Rookmelders, onder te verdelen in optische en ionisatierookmelders

Omschrijving (NEN 2535): een optische rookmelder is gevoelig voor verbrandingsproducten die de absorptie of reflectie van licht in het infrarode, zichtbare en/of ultraviolette gebied van het elektromagnetisch spectrum kunnen beïnvloeden.

Omschrijving (NEN 2535): een ionisatierookmelder is gevoelig voor verbrandingsproducten die de ionisatiestroom in de melder kunnen beïnvloeden.

Overwegingen: - (geen voorbeelden van melders gevonden).

\begin{tabular}{llll} 
Detectiesysteem & Categorie & Werkingsprincipe & Toepassingen \\
$\begin{array}{l}\text { Standaard } \\
\text { rookmelder }\end{array}$ & Optische rookmelder & $\begin{array}{l}\text { Rookmelder wordt geactiveerd door de } \\
\text { verstrooiing of verduistering van het } \\
\text { licht op de sensor }\end{array}$ & $\begin{array}{l}\text { Woningen, kantoor, } \\
\text { industrie }\end{array}$ \\
\hline
\end{tabular}

Bron: divers (algemeen verkrijgbaar)

Overwegingen: Een optische rookmelder is vanwege het werkingsprincipe slechts in enkele technische ruimten goed toepasbaar. Dit werkingsprincipe wordt snel aangetast door stof, vocht en ammoniak, en daarom zijn optische rookmelders niet geschikt voor ruimten die lucht uitwisselen met dierverblijven.

b. Thermische melders, onder te verdelen in de diverse temperatuurklassen

Omschrijving (NEN 2535): een thermische melder is gevoelig voor temperatuursverhoging. Overwegingen: er zijn twee soorten thermische melders: een thermomaximaal melder (genereert een brandalarm als de temperatuur in een ruimte boven een bepaalde grenswaarde komt) en een thermodifferentiaal melder (genereert een brandalarm als de temperatuur in een ruimte binnen een bepaalde tijd teveel stijgt). Thermische melders worden al veel gebruikt in de veehouderij. Hiervoor worden veelal sensoren gebruikt die normaal de temperatuur in de stal regelen: deze zijn bestand tegen zware omstandigheden met stof, vocht en ammoniak. Deze sensoren worden gekoppeld aan een aparte klimaatcomputer die wordt gebruikt als brandmeldcentrale. De klimaatcomputer geeft vervolgens een alarm bij een temperatuurstijging van bv. meer dan $5^{\circ} \mathrm{C}$ per minuut, of bij een absolute overschrijding van $68^{\circ} \mathrm{C}$. Dit is dus een combinatie van een thermodifferentiaal en 
thermomaximaal melder. Deze sensoren worden op risicoplekken opgehangen zoals technische ruimtes, maar ook door de stal heen verspreid.

Er zijn thermische melders op de markt in combinatie met automatische bluspatronen. Een aerosol gekoppeld aan een thermomaximaal sensor is goed om snel een beginnende brand te doven. Toch moet hier altijd een doormelding plaatsvinden vanwege het risico dat de brand weer oplaait, of dat er onderdelen van het systeem zijn uitgeschakeld. Als dit niet het geval is, geeft een aerosol met thermomaximaal sensor een schijnveiligheid.

Voorbeeld van thermische melder met bluspatroon:

\begin{tabular}{llll} 
Detectiesysteem & Categorie & Werkingsprincipe & Toepassingen \\
AF-X Fireblocker & Thermische & Wordt aangestuurd door verschillende sensoren & Agrarisch, industrie, \\
& melder/ overig & $\begin{array}{l}\text { of activeert zichzelf boven } 330^{\circ} \mathrm{C} \text {. Hierna } \\
\text { komen aerosolen vrij die brand snel doven }\end{array}$ & bouw, ICT ruimten \\
\hline
\end{tabular}

Bron: https://www.afxfiresolutions.com/site/brandbeveiliging-agrarisch

\section{c. Vlammenmelders, onder te verdelen in infrarood- en ultravioletvlammenmelders}

Omschrijving (NEN 2535): een vlammenmelder is een melder die reageert op vlammen bij brand. Overwegingen: Deze melders meten door middel van een fotocel de aanwezigheid van infrarood of ultraviolet licht in een speciaal gesorteerd frequentiegebied, de frequentie van de te verwachten brand. Een beginnende brand moet een bepaalde omvang hebben voordat deze de benodigde hoeveelheid straling gaat uitzenden voor activeren van de melder. Dan kan al wel sprake zijn van rookontwikkeling.

Voorbeeld van vlamdetectie:

\begin{tabular}{lll} 
Detectiesysteem & Categorie & Werkingsprincipe \\
Vlamdetectie & Vlammenmelder & Gevoelig voor ultraviolet en/of infrarood licht \\
& van de brandhaard \\
\hline
\end{tabular}

Bron: https://www.saval.nl/producten/vlamdetectie/105/229/

Vlamdetectie wordt vooral toegepast bij een verhoogd explosierisico. Elke brandende stof heeft een kenmerkend stralingspatroon. Het is dus belangrijk om te kiezen voor een type vlammenmelder dat past bij de in de ruimte aanwezige stoffen en hun stralingspatroon. Voor technische ruimten in veestallen is dit type detectie minder relevant: het vindt vooral toepassing in de chemische industrie.

\section{d. Combinaties van bovengenoemde melders:}

Omschrijving: Multisensoren bevatten vaak een optisch en thermisch deel, deze combinatie kan snel reageren. Het optische deel kan worden gehinderd door stof, vocht en ammoniak. Zie verder bij optische en thermische melders.

\section{e. Lineaire optische rookmelders}

Omschrijving (NEN 2535): een lineair optische rookmelder bestaat uit ten minste een zender en een ontvanger en eventueel een reflector, die rook detecteert door de vermindering van intensiteit of wisselende intensiteit van een optische straal.

Overwegingen: zie eerder 'bij optische rookmelders'. Lineair optische rookmelders zijn vooral geschikt voor grote ruimten. Er kunnen gevoeligheidsdrempels voor meldingen worden ingesteld afhankelijk van de condities in de ruimte.

Voorbeeld van een lineair optische rookmelder:

\begin{tabular}{lll} 
Detectiesysteem & Categorie & Werkingsprincipe \\
Fireray $50 \mathrm{RV}$ & Lineaire optische & Sensor reageert op rookdeeltjes of verbuiging Goepassingen \\
& rookmelder & van lichtstraal door warmte \\
\hline
\end{tabular}

Bron: https://resource.boschsecurity.com/documents/Data_sheet_enUS_1281214987.pdf 


\section{f. Lineaire thermische melders}

Omschrijving (NEN 2535): een lineaire thermische melder reageert op een temperatuursverhoging in de nabijheid van een continue verbinding.

Overwegingen: Lineaire thermische melders worden nog weinig toegepast in de agrarische sector. Ze worden vaker toegepast in combinatie met zonnepanelen. De thermische leiding wordt in kabelgoten gelegd en langs risicoplekken geleid. De lineaire thermische melder geeft bij een overschrijding van $68^{\circ} \mathrm{C}$ een alarm af. Als kabels in de kabelgoot deze temperatuur bereiken, gaat het alarm al wel af, maar is vaak nog geen sprake van brand (preventief). Eventueel kan deze techniek ervoor zorgen dat na een alarm de elektriciteit (in het betreffende cricuit) wordt afgesloten, waardoor brand kan worden voorkomen. Lineaire thermische melders zijn goed bestand tegen stof, vocht en ammoniak.

Voorbeeld van een lineair thermische melder:

\begin{tabular}{|c|c|c|c|}
\hline Detectiesysteem & Categorie & Werkingsprincipe & Toepassingen \\
\hline $\begin{array}{l}\text { Line-type heat } \\
\text { detector ADW } 535\end{array}$ & $\begin{array}{l}\text { Lineaire } \\
\text { thermische melder }\end{array}$ & $\begin{array}{l}\text { Buis/kabel loopt door ruimte en reageert op } \\
\text { druk/temperatuur verschil }\end{array}$ & $\begin{array}{l}\text { Grote ruimtes, } \\
\text { extreme } \\
\text { omgevingen zoals } \\
\text { stallen }\end{array}$ \\
\hline
\end{tabular}

\section{g. Aspiratierookmelders}

Omschrijving (NEN 2535): bij een aspiratierookmelder worden lucht en aerosolen door een leidingnetwerk met aanzuigopeningen aangezogen (via ventilator of pomp) en getransporteerd naar één of meer gevoelige elementen.

Overwegingen: Aspiratierookmelders worden gebruikt op plaatsen met afwijkende luchtstromen of waar een snellere detectie nodig is. Aspiratierookmelders zijn in staat snel te reageren op rookvorming. Het systeem is geschikt om zowel de hele stal als technische ruimtes te monitoren met verschillende aanzuigpunten. Wanneer een filter in de aanzuigleiding wordt geplaats waarmee vocht en stof zonder vertraging of verstoppingen uit de luchtstroom kunnen worden gehaald, is deze manier van branddetectie ook geschikt voor een dierverblijf. Om te voorkomen dat stof of vocht de werking vermindert, is regelmatig onderhoud aan dit systeem nodig. Voor alleen technische ruimten is het systeem waarschijnlijk te duur.

Voorbeelden van aspiratierookmelders:

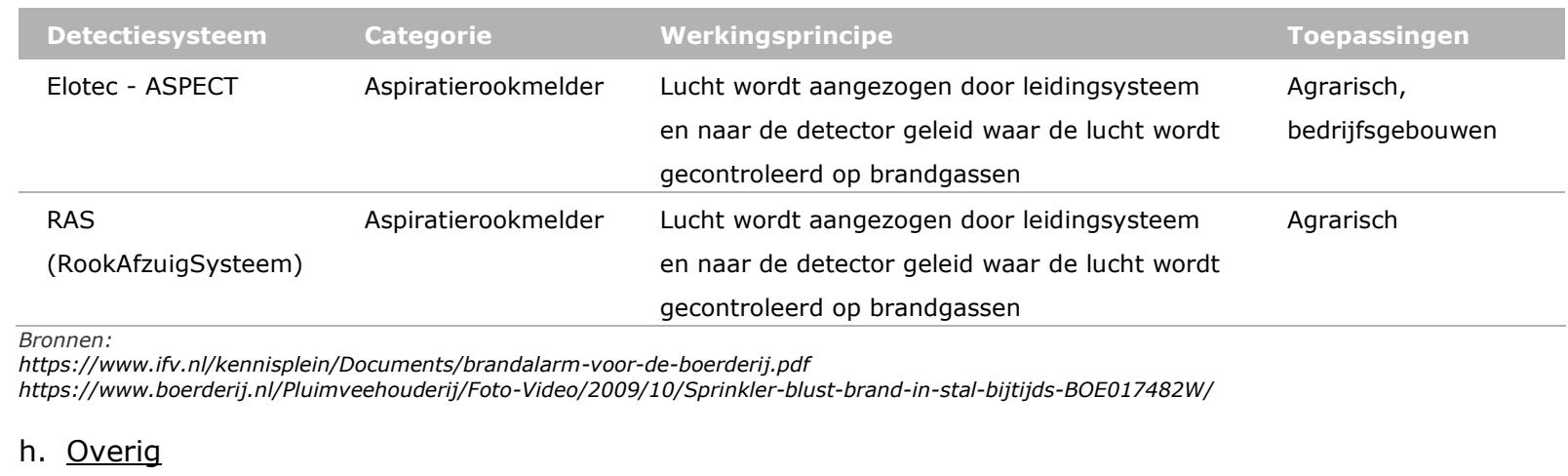

Omschrijving: We noemen hier videogebaseerde branddetectie: permanente camerabewaking waarbij branden worden gedetecteerd aan de bron. De camera fungeert als controlerend signaalinitiërend apparaat. Alarmen moeten worden gecontroleerd door een operator in een ontvangststation voor alarmen, omdat er (nog) geen normen bestaan. Om die reden is een videogebaseerd systeem op dit moment minder geschikt voor toepassing op veebedrijven. Bij doorontwikkeling kan het mogelijk wel relevanter worden, m.n. indien camerasystemen ook voor andere managementdoeleinden in veestallen een functie kunnen vervullen. 
Voorbeeld van een videogebaseerd detectiesysteem:

\begin{tabular}{|c|c|c|c|}
\hline Detectiesysteem & Categorie & Werkingsprincipe & Toepassingen \\
\hline $\begin{array}{l}\text { AVIOTEC IP starlight } \\
8000\end{array}$ & Overig & $\begin{array}{l}\text { Snelle detectie van rook en vuur door middel van } \\
\text { video gebaseerde branddetectie }\end{array}$ & $\begin{array}{l}\text { Industrie, transport, } \\
\text { magazijnen en } \\
\text { energie- en } \\
\text { nutsbedrijven }\end{array}$ \\
\hline
\end{tabular}

Bron: https://www.boschsecurity.com/be/nl/producten/branddetectiesystemen/videogebaseerde-branddetectie/ 


\section{Toetsing categorieën detectie- systemen aan de ontwikkelde criteria}

In figuur 2 is gevisualiseerd welke typen brandmelders in welke fase van een ontwikkelende brand (de brandkromme uit figuur 1) een signaal kunnen geven.

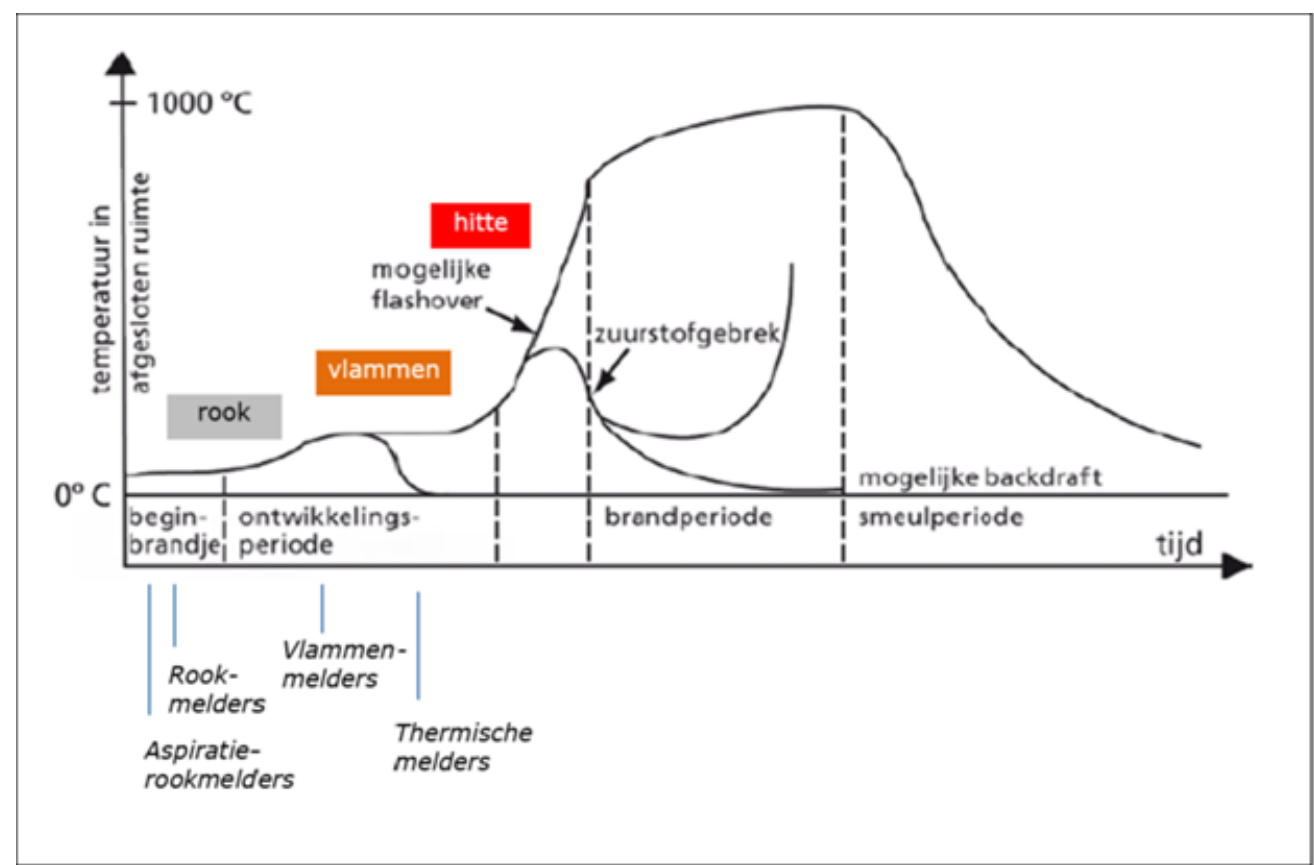

Figuur 2 Type melders en brandfase warin ze relevant zijn (bewerking brandkromme IFV, 2017).

Optische rookmelders en aspiratierookmelders detecteren een beginnende brand in de smeulfase (rook is binnen 1-3 minuten te detecteren). Iets later in de tijd (na 5 tot 8 minuten) detecteren vlammenmelders straling van brandende stoffen (mits hun frequentiegebied is afgestemd op het stralingspatroon van de betreffende stof). Thermische melders detecteren een stijging in temperatuur 7-10 minuten na het begin van de brand.

Om inzichtelijk te maken welke detectiesystemen potentieel toepasbaar zijn in technische ruimten van veestallen, zijn in tabel 5 de verschillende categorieën brandmelders op hoofdlijnen getoetst aan de criteria (functionele eisen en gebruikerswensen) zoals geformuleerd in paragraaf 5.

Tabel 5 Toetsing van de categorieën brandmelders aan de opgestelde criteria (functionele en gebruikerseisen excl. het kostenaspect).

Legenda: + = positief punt ; - = negatief punt van de categorie brandmelder in technische ruimten van veestallen

\begin{tabular}{|c|c|c|c|c|c|}
\hline & $\begin{array}{l}\text { Snelheid } \\
\text { detectie }\end{array}$ & $\begin{array}{l}\text { Ongewenste/ } \\
\text { onechte } \\
\text { meldingen }\end{array}$ & $\begin{array}{l}\text { Door- } \\
\text { melding }\end{array}$ & $\begin{array}{l}\text { Gebruiks- } \\
\text { vriendelijk/ } \\
\text { weinig } \\
\text { onderhoud }\end{array}$ & $\begin{array}{l}\text { Koppeling } \\
\text { klimaat- } \\
\text { systeem }\end{array}$ \\
\hline a. Optische rookmelders & + & - & - & $+/-$ & - \\
\hline b. Thermische melders & - & + & + & + & + \\
\hline c. Vlammenmelders & - & + & + & - & - \\
\hline d. Combinatiemelders & + & - & + & $+/-$ & + \\
\hline e. Lineaire optische rookmelders & + & - & + & $+/-$ & - \\
\hline f. Lineaire thermische melders & $+^{1}$ & + & + & + & + \\
\hline g. Aspiratierookmelders & + & + & + & - & - \\
\hline f. Overig: cameradetectie & $?$ & $?$ & + & - & - \\
\hline
\end{tabular}

${ }^{1}$ ook preventief inzetbaar 
De volgende categorieën melders voldoen aan de meeste van de genoemde functionele en gebruikerseisen voor technische ruimten van stallen in de intensieve veehouderij:

- Rookmelders

- Thermische melders

- $\quad$ Lineaire thermische melders

- Combinatiemelders (meestal combinatie rook en thermisch)

- Aspiratierookmelders

Het is afhankelijk van de specifieke omstandigheden in de betreffende technische ruimte van de veestal of ze ook daadwerkelijk perspectief bieden. Specifieke omstandigheden zoals aanwezige apparatuur, materialen, luchtkwaliteit, stof, oppervlakte en hoogte van de ruimte et cetera zijn daarvoor relevant.

In de volgende paragraaf wordt een ruwe inschatting gegeven van de investerings- en jaarkosten van typen melders die potentieel toepasbaar zijn in technische ruimten van veestallen. 


\section{Kosten van potentieel toepasbare systemen in de sectoren}

In Bokma-Bakker et al. (2017) en Koning et al. (2018) worden indicatieve bedragen genoemd voor branddetectie in de technische ruimten. Voor de in deze studie behandelde diercategorieën variëren die van $€ 2.300$ tot $€ 3$ 3.800. Dit zijn ruwe indicaties. Om een goed beeld te krijgen van de benodigde investeringen is een meer uitgebreide inventarisatie nodig, aan de hand van plattegronden van bedrijven. De deelnemers aan de discussiebijeenkomst hebben een ruwe indicatie afgegeven van de benodigde investeringen voor detectieapparatuur die geschikt is om toe te passen in technische ruimten van de genoemde diercategorieën. Hierbij is ook zo goed mogelijk rekening gehouden met kosten die gemoeid zijn met de montage en nevenapparatuur. Hierna zijn indicatieve bedragen opgenomen voor de detectiesystemen die volgens hoofdstuk 7 toepasbaar zijn in technische ruimten van veestallen. Ook zijn eventuele kosten van onderhoud benoemd.

- Rookmelders;

Een geschikte rookmelder vraagt een investering van $€ 125$ per stuk voor een ruimte met een oppervlakte van maximaal $60 \mathrm{~m}^{2}$. Voor meerdere ruimten komt een investering, inclusief aanleg, op $€ 1.000$ tot $€ 1.500$. De kanttekening erbij is dat dit type melder geen doormeldingen kan geven. De onderhoudskosten ervan zijn relatief laag, ca. $€ 10$ per stuk per jaar.

- Thermische melders;

Gebruik van alleen een thermische melder is niet raadzaam. Door deze aan te sluiten op een klimaatcomputer kan gebruik worden gemaakt van de thermodifferentiaal en thermomaximaal regelingen. Inclusief montage en voldoende voelers wordt de investering in een dergelijk systeem geschat op ca. $€ 5.000$ voor alleen de technische ruimten. De onderhoudskosten zijn ca. $€ 500$ per jaar.

- $\quad$ Lineaire thermische melders;

De totale investering in lineair thermische melders is afhankelijk van het aantal meters dat nodig is. Dit vraagt ca. $€ 15$ - $€ 20$ per meter. Daarnaast is centrale apparatuur nodig, waarvan de investering afhankelijk is van de leverancier. Uitgangspunt is dat deze centrale regelapparatuur een investering vraagt van $€ 1.500$ tot $€ 2.500$. De totale investeringen kunnen dan variëren van $€ 2.250$ tot $€ 4.500$ (bij 50-100 meter draad). De onderhoudskosten (controle van de draden) bedragen mogelijk $€ 500$ tot $€ 1.000$ per jaar.

- Combinatiemelders (meestal combinatie rook en thermisch); Hiervan zijn geen goede indicaties van investeringen verkregen op dit moment.

- Aspiratierookmelders;

Voor de centrale apparatuur voor dit type meldinstallatie variëren de investeringen van $€ 3.000$ tot $€ 5$ 500. Daarnaast zijn leidingen nodig voor het aanzuigen van de lucht. De totale investeringen zijn daardoor afhankelijk van het aantal ruimten en de afstanden tot de centrale apparatuur. Deze kunnen oplopen tot $€$ 10.000. De onderhoudskosten voor alleen de centrale apparatuur bedraagt ca. $€ 150$ per jaar. Daarbovenop komen de onderhoudskosten (schoonmaken) van de buizen. Deze zijn afhankelijk van de gekozen uitvoering. 


\section{$9 \quad$ Conclusies en discussie}

In dit beknopte onderzoek stond beantwoording van twee kennisvragen centraal:

- Aan welke criteria moeten branddetectiesystemen bij gebruik in technische ruimten van veehouderijen voldoen?

- Welke brand- en rookdetectiesystemen zijn geschikt voor gebruik in technische ruimten van veehouderijen?

Ten aanzien van de kennisvragen concluderen we op basis van de bevindingen zoals beschreven in de voorgaande paragrafen het volgende:

Belangrijke functionele eisen aan rook- en branddetectie in technische ruimten van veestallen met het oog op beperken van dierlijke slachtoffers van stalbrand zijn:

- 'Snelle' detectie: binnen één tot enkele minuten na het ontstaan van de brand.

- Beperkt aantal ongewenste of onechte brandmeldingen, ook in technische ruimten met stof, vocht of ammoniak (zie rekenregels NEN 2535 per type detectiesysteem hiervoor).

- Directe doormelding van brandalarm: naar mobiel van veehouder, aanwezig personeel en/of andere personen in de directe omgeving van de veehouderij (familieleden, buren).

[Voor algemene functionele eisen aan brandmeldsystemen: zie NEN 2535]

Belangrijke gebruikerseisen zijn:

- Hoge betrouwbaarheid: weinig onechte en ongewenste meldingen;

- Gebruiksvriendelijk en weinig onderhoud;

- Lage kosten (investerings- en jaarlijkse kosten);

- Bij voorkeur koppeling aan al bestaand systeem in het bedrijf (bv. klimaatcomputer);

- In het ideale geval is branddetectie onderdeel van een integraal systeem: na branddetectie directe doormelding en automatisch sluiten van branddeuren, stopzetten van draaiende mesten eierbanden om verspreiding naar naastgelegen compartiment te voorkomen, eventueel aanwezige automatische blussystemen activeren et cetera.

Om te blijven functioneren dient er regelmatig onderhoud te worden gepleegd aan branddetectiesystemen, regelmatige tests op werkzaamheid te worden uitgevoerd en een logboek van testen te worden bijgehouden (randvoorwaarden). NEN 2654-1:2018 geeft hiervoor handvatten, evenals het daarmee samenhangende CCV-Inspectieschema Brandmeldinstallaties ${ }^{1}$ (op basis waarvan andere gebruiksfuncties dan 'lichte industrie' waar veehouderijen onder vallen over een geldig inspectiecertificaat voor hun brandmeldinstallaties dienen te beschikken).

Op basis van de criteria zijn de volgende categorieën melders in potentie toepasbaar in technische ruimten van stallen in de intensieve veehouderij:

- Rookmelders

- Thermische melders

- $\quad$ Lineaire thermische melders

- Combinatiemelders (meestal combinatie rook en thermisch))

- Aspiratierookmelders

Het is afhankelijk van de specifieke omstandigheden in de betreffende technische ruimte van de veestal of ze ook daadwerkelijk perspectief bieden. Specifieke omstandigheden zoals aanwezige apparatuur, materialen, luchtkwaliteit, stof, oppervlakte en hoogte van de ruimte, et cetera zijn daarvoor relevant. Daarnaast zal het kostenaspect een rol spelen. Bij systemen die werken met een centrale unit (o.a. aspratierookmelders, lineair thermische melders) kan toepassing uitsluitend in technische ruimten minder kosteneffectief zijn: dergelijke systemen zijn o.a. meer toegesneden (en qua technisch systeem in principe geschikt) op gelijktijdige toepassing in dierverblijven.

\footnotetext{
${ }^{1}$ https://hetccv.nl/certificatie-inspectie/brandveiligheid/inspectie-brandbeveiliging/documenten/ccv-inspectieschemabrandbeveiligingssystemen/
} 


\section{Detectie en brandcompartimentering}

Zoals beargumenteerd in paragraaf 4 heeft een snelle detectie in technische ruimten die geen apart brandcompartiment zijn (min. 60 minuten brandwerend) uit oogpunt van beperken van dierlijke slachtoffers in nabijgelegen ruimten alleen zin als er ook een snelle opvolging (d.w.z. bestrijding van de nog lokale brand) op het signaal mogelijk is. Is die snelle opvolging niet mogelijk, dan heeft investeren in branddetectiesystemen daar beperkt tot geen meerwaarde. Het is dan zinvol om te onderzoeken of en zo ja welke praktisch haalbare mogelijkheden er zijn om dergelijke technische ruimten uit te rusten met voldoende brandwerendheid (i.c. vloer-wanden-plafond-deuren-deurposten voorzien van goed gemonteerde brandwerende platen/materialen), zodat feitelijk een apart brandcompartiment wordt gecreëerd. Dat kan in bepaalde gevallen een brandcompartiment van beperkte omvang zijn: bv. een brandwerende kast rondom een schakelkast. Zodra die brandwerendheid (min. 60 minuten) is gerealiseerd, dan is investeren in branddetectieapparatuur in de betreffende ruimte uiteraard zinvol.

\section{Preventie versus detectie}

Brand voorkomen is natuurlijk beter dan het detecteren van een brand. Veel stalbranden hebben een technische oorzaak (kortsluiting, oververhitting van elektrische systemen e.d.). Er zijn technische mogelijkheden om brandgevaarlijke afwijkingen te detecteren voordat er daadwerkelijk brand ontstaat (d.w.z. preventieve detectiesystemen). Dit vormde geen onderdeel van het onderzoek, maar we noemen kort een drietal mogelijkheden op dit vlak.

Vlamboogdetectie Een elektrische vlamboog kan ontstaan door losse kabels of contacten, hierbij komt hitte vrij of er ontstaan vonken. Doordat er geen lekstroom naar de aarde gaat, detecteert de aardlekschakelaar dit niet. Vlamboogdetectie kan dit wel herkennen en het elektrische systeem uitschakelen voordat de vonken brand geven.

Elektronische beveiliging Elektronische beveiliging kan voorkómen dat een systeem meer stroom gaat verbruiken dan ingesteld, want dit zou kunnen duiden op overbelasting of kortsluitstromen die een mogelijke bron van brandgevaar zijn. Deze detectie is gericht op systemen met lagere voltages.

Continue isolatieweerstandsmeting Dit kan worden toegepast op de gehele elektrische installatie en detecteert als het systeem meer elektriciteit verbruikt door bijvoorbeeld aangevreten kabels door ongedierte.

Het is zinvol om na te gaan welke preventieve detectiesystemen praktisch toepasbaar en haalbaar zijn op bestaande (intensieve) veehouderijbedrijven, in technische ruimten én in dierverblijven, en wat de verwachte effectiviteit ervan is uit oogpunt van het voorkómen van het ontstaan van brand in veestallen en het voorkómen van dierlijke slachtoffers. 


\section{Literatuur}

Bouwbesluit 2012.

https://www.bouwbesluitonline.nl/docs/wet/bb2012

Bokma-Bakker, M.H., S. Bokma, H.H. Ellen, R.R. Hagen, C. van Ruijven, 2017. Evaluatie Actieplan Stalbranden 2012-2016. Wageningen Livestock Research, Rapport 1035.

Instituut Fysieke Veiligheid (IFV), 2017. Basis voor brandveiligheid. De onderbouwing van brandbeveiliging in gebouwen. ISBN: 978-90-5643-463-2

Koning, M., M. Bolt en C. Bogaards. 2018. Stalbrandpreventie. Kosteneffectiviteit, uitvoerbaarheid en handhaafbaarheid van brandpreventiemaatregelen bij bestaande stallen. Economisch Instituut voor de Bouw (EIB).

NEN-norm 2535:2017 Brandveiligheid van gebouwen - Brandmeldinstallaties - Systeem- en kwaliteitseisen en projectierichtlijnen.

NEN-norm 2654-1+C1:2018 (Beheer, controle en onderhoud van brandbeveiligingsinstallaties - Deel 1: Brandmeldinstallaties. 


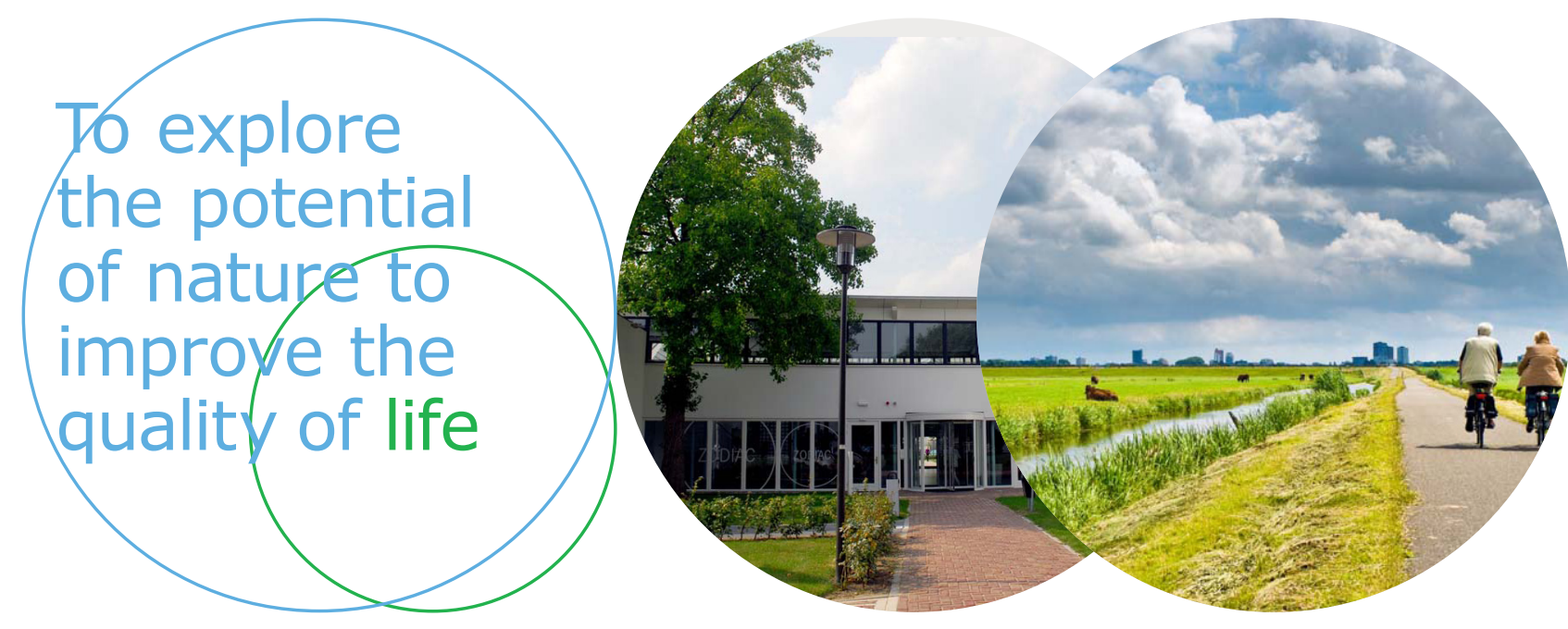

Wageningen Livestock Research Postbus 338

Wageningen Livestock Research ontwikkelt kennis voor een zorgvuldige en $6700 \mathrm{AH}$ Wageningen

T 0317483953

renderende veehouderij, vertaalt deze naar praktijkgerichte oplossingen en innovaties, en zorgt voor doorstroming van deze kennis. Onze wetenschappelijke E info.livestockresearch@wur.nl www.wur.nl/ livestock-research kennis op het gebied van veehouderijsystemen en van voeding, genetica, welzijn en milieu-impact van landbouwhuisdieren integreren we, samen met onze klanten, tot veehouderijconcepten voor de 21 e eeuw.

De missie van Wageningen University \& Research is 'To explore the potential of nature to improve the quality of life'. Binnen Wageningen University \& Research bundelen 9 gespecialiseerde onderzoeksinstituten van Stichting Wageningen Research en Wageningen University hun krachten om bij te dragen aan de oplossing van belangrijke vragen in het domein van gezonde voeding en leefomgeving. Met ongeveer 30 vestigingen, 6.500 medewerkers en 10.000 studenten behoort Wageningen University \& Research wereldwijd tot de aansprekende kennisinstellingen binnen haar domein. De integrale benadering van de vraagstukken en de samenwerking tussen verschillende disciplines vormen het hart van de unieke Wageningen aanpak. 